\title{
ONLINE LEARNING DURING THE COVID-19 PANDEMIC FROM THE PERSPECTIVE OF PARSONS' STRUCTURAL FUNCTIONAL THEORY
}

\author{
Ellya Rohati \\ Universitas Muhammadiyah Sidoarjo \\ ellyasmamda@gmail.com
}

\section{Isa Anshori}

Universitas Islam Negeri Sunan Ampel Surabaya

isaanshori67@gmail.com

\section{Mufarrihul Hazin}

STAI Ma'had Aly Al-Hikam Malang

mufarrihulhazin@gmail.com

\begin{abstract}
The Covid-19 pandemic results social changes significantly in the world of education, from offline learning to online learning. In order not to experience cultural lag, this article offers a functional structural theory initiated by Talcott Parsons to examine the implementation of online learning, through the AGIL (Adaptation, Goal Attainment, Integration, Latency) scheme. This article recommends to all involved and interested parties to immediately adapt to online learning, so that the online learning can meet the educational and learning objectives that have been proclaimed. Therefore, integration between three educational centres is needed, such as school, families and communities; so that education as a cultural pattern inherent in Indonesian society is maintained even during the Covid-19 pandemic. More than that, the implementation of online learning must maintain a new cultural pattern during the Covid-19 pandemic, namely complying with health protocol standards.
\end{abstract}

Keywords: Functionalism, the Covid-19 Pandemic, Online Learning, Structural Functional, Talcott Parsons. 


\section{A. Introduction}

Education is needed by everyone to develop their potential in a conscious and planned manner. In order to achieve this goal, education experiences dynamic problems along with the changing times.

Throughout history, every era has undergone major and minor changes. While the change of the old order of life to the new order, according to a massive adaptive attitude. This is in line with the statement of Ali bin Abi Thalib in educational context: "Educate your children according to the times. They will face a different time from yours" (Dimyathi, 2017, p. 100).

In March 2020, the Covid-19 outbreaks was confirmed to have entered Indonesia. Based on WHO advice, Indonesia declared the Covid-19 pandemic a national disaster on April 13 ${ }^{\text {rd }}, 2020$ through the Presidential Decree of the Republic of Indonesia Number 12 of 2020 concerning The Designation of Non-natural Disaster Spreading Covid-19 as a National Disaster (Komite Penanganan Covid-19 dan Pemulihan Ekonomi Nasional (KPC PEN), 2020). To reduce the spread of Covid-19, the government issued a policy in education through circular latter number 4 of 2020 which states that the learning process is carried out from home or Distance Learning. (Pusdiklat Kemdikbud, 2020)

In the policy, it is explained that education must continue to be carried out by implementing social restriction and waiving the face-to-face learning system (offline). The learning process is done online through computer, laptop, smartphones which connected to the internet. In online learning, teachers teach through social and electronic media such as WhatsApp, Facebook, Instagram, YouTube, and television. During online learning, the teacher uses a student oriented learning approach (Rusman, 2014).

Online learning caused social change in education sector, as it require teachers and students to be technology literate. This transition to social change has had unpredictable consequences (Rasyid, 2015). For example, online learning causes teachers to experience various obstacles in conditioning students to enter the class on time; lesson hours are delayed; unmanageable learning assignments. As a result, learning is not effective and makes students do not understand the material being studied (Rahmah Fitriyani, 2020) 
Among the causes are that not all teachers are proficient and master in technology, and also not familiar with online learning, because they are accustomed to offline learning (Isa Anshori, 2020). Therefore, to overcome obstacles during online learning, teachers must improve their competencies, especially the competence of mastering science and technology and literacy; classroom management, communication and social skills; for online learning to be successful (Sudrajat, 2020).

During the online learning, teachers are also required to be able to maintain students' motivation and independence in learning. This is because students who are constantly at home and have minimal social interaction will easily feel bored, so that the students difficult to understand the lesson when participating in online learning (Isa Anshori, 2020). The empirical evidence of a decrease in student learning motivation in online learning can be found in the following research result:

To begin with, Suryaningsih (2020) revealed the evidence of a decrease in student learning motivation which was reflected in the reduced response of students in responding to communication made by teacher through WhatsApp group (Suryaningsih, 2020).

In addition, Cahyani (2020) revealed that the decline in students' learning motivation was caused during online learning, students who studied at home without being accompanied by a teacher, so that students felt they did not get praise, reprimand, punishment and advice from the teacher, which could strengthen intrinsic motivation (Adhetya Cahyani, 2020). While intrinsic and extrinsic motivation is very important for the success of the learning process (Emda, 2017).

In conclusion, the problem of online learning is caused by the cultural lag experienced by teachers, students and parents in carrying out online learning which is a new cultural pattern in society during the Covid-19 pandemic. Therefore, to overcome the cultural lag, this article will examine online learning during the Covid-19 pandemic from the perspective of the sociology of education, especially functionalism theory.

This article uses a qualitative approach and a literature study because it utilize various library sources to obtain research data (Zed, 2014). Then 
the data obtained will be compiled, analysed, and concluded, so produce information as research findings presented in a descriptive-analytic.

\section{B. Relation between Teachers, Students and Parents in online Learning}

In this pandemic era, teachers must be sensitive to changes and development that occur. For example, teachers must be able to adapt to new policies related to the implementation of online learning. Therefore, teacher competencies need to be developed and trained in order to be able to create student progress in online learning activities during the pandemic (Susanto, 2016).

With qualified competencies, teachers have the potential to manage classes in online learning, use digital technology-based learning media, and utilize digital technology as a learning resource (Rizki Setiawan, 2020 ). As a learning manager, teacher competence is an important factor influencing the success of online learning. The learning indicators that are classified as successful include learning that is fun, flexible, efficient, short, practical, fast, precise, safe, easy, saving time and energy, so as to generate, maintain and increase student learning motivation (Nasution, 2009, pp. 116-117).

Online learning makes the learning process can not to be fully controlled by the teacher. Online learning was developed to realize an integrated education system that can build connectivity between components in education (Poncojari Wahyono, 2020). For example, it was needed a good cooperation and communication between parents and teachers to guide students. Therefore, the teacher is tasked to socialize and simulate online learning whether to students or parents, so that they are ready and able to carry out their own roles. This is done to overcome the difficulties in online learning, for example the problem of parents who have difficulty acting as 'teachers' at home when online learning (Sudrajat, 2020). 
As a learning agent, the teacher is tasked to provide assistance, encouragement, guidance and discipline in order to maintain and increase motivation of the students in learning (Maunah, 2019). Therefore, teachers need to design meaningful online learning. That is a relevant learning whether in context or content to students' lives. In online learning, teachers are expected to be more creative, innovative and technology literate, to create teaching materials that attract students' interest and motivation (Syaharuddin, 2020).

The role of students in online learning is to increase their learning motivation. The existence of learning motivation are to keep students' excited, not complaining and not bored in doing the assignments that was given by the teacher (Ria Yunitasari, 2020). This is because learning motivation is a driving force a person so they can bring up learning actions and provide direction to achieve the learning goals (Lilik Agustina, 2017).

The high motivation in learning can be seen from the curiosity and perseverance of students in doing assignments, have a tenacious nature and keep enthusiastic in facing every challenge, independence and high interest in learning (Sadirman, 2012, p. 84).

If students' learning motivation is low, the teacher can increase students' motivation in various ways. For the examples are giving gifts (reward); holding competitions between individuals or groups; providing numbers as learning scores; fostering self-awareness (ego-involvement) of students on the importance of completing assignments from the teacher; and also providing positive challenges, evaluations and reinforcements to students (Sadirman, 2012, p. 92).

\section{Online Learning from the Perspective of Talcott Parsons' Structural Functional Theory}

The Covid-19 pandemic has proven to have changed the old order of education which tends to be offline, towards a new order which tends to be online. This change can be seen holistically through the sociological analysis of education, for example the theory of functionalism which emphasizes the elements of stability, function, integrity, coordination and consensus. In this perspective, the community system consists of various elements that are 
related to each other. The existence of these interrelationships is symbioticmutualistic and consciously tends towards equilibrium, but remains dynamic.

Specifically, this article analyzes online learning from the perspective of structural functional theory initiated by Talcott Parsons. Based on this theory, society is a social system consisting of parts or elements that are interrelated and united in balance. Changes that occur in one part will also bring changes to other parts (Ritzer, 2013, p. 21).

According to Parsons, to realize an orderly society, it can be done with an action which is known as the AGIL (Adaption, Goal Attainment, Integration, Latency) scheme (Craib, 1986 , p. 58).

The following is a more detailed description of AGIL by Parsons (George Ritzer, 2014, p. 117):

\section{Adaptation}

It means the need to adapt to the environment to cope the critical external situation. Online learning is an example of adaptation to the Covid19 pandemic. In other words, the transition of the education system from offline learning to online learning, has been determined by stakeholders in Indonesian education units to save the world of education (Ichsan, 2020 ).

On the other hand, adaptation must be done proportionally and professionally by adjusting the tasks and needs in online learning. For example, schools as a subsystem of implementing educational functions, in collaboration with parents to adapt with students' environment and the society. Teachers and parents should collaborate in motivating the student to follow online learning actively. Through a good collaboration, the institution of the school can help the society to adapt with the external reality of this Covid 19 pandemic (Ichsan, 2020 ).

\section{Goal Attainment}

It means people's behavior always have a specific goal. But, the goals of individual are not often appropriate with the goal of the larger social environment. Because of that reason, the individual should adapt with the greater importance such groups or society.

Online learning was held with many goals, such as to save education, to protect the citizens of the education unit from the negative effect of Covid 
19 pandemic, to avoid the spread and contagion Covid 19, and the fulfillment of psychosocial support. In this case, online learning was considered as the best solution to ensure the fulfillment of students' right in getting education service during the emergency time of Covid 19 (Kementerian Pendidikan dan Kebudayan, 2020). Beside that reason, the goal of online learning is to optimize accompaniment of parents towards their children's education. It is because parents' education not only useful for upgrading the children's intellectuality but also to fulfill the children's emotional need (Ichsan, 2020 ).

\section{Integration}

It means the need of the system to coordinate and make a relationship between among the member of the system, and also a relation among three important function of other components (A, G, L). This integration showed the social solidarity. The social solidarity will destroyed if each components of a part system showed an individual interest.

Based on Parsons, the key of protecting integrity are internalization and socialization (Syawaludin, 2014). In online learning context, internalization directed to student about the way to learn in their own house so the online learning can be implemented as the goals. Meanwhile, socialization directed into important information about child achievement development or the newest information from the education stakeholder authorities (Ichsan, 2020 ).

For example, to avoid the error and mistakes in online learning implementation, the school should give an instructions to the teacher and also students in order to make the learning more effective. Because of this effectiveness, the learning goals can be achieved properly (George Ritzer, 2014).

More than that, educational system in Covid-19 pandemic should manage the relation among the related components harmoniously. For example, school, family, society, educational service, and health workers. Integration among the education stakeholders is the best solution to save the quality of education in pandemic era. In other words, online learning necessitating the harmonious integration of the three educational centers 
namely family, school, and society. It creates the online learning effective, efficient and full of happiness for the students.

\section{Latency}

It means the system should improve, complete and maintain the cultural patterns each part of the system.

Education is a cultural pattern that must be maintained. Therefore, even during the Covid-19 pandemic, education is still carried out. This is the significance of online learning in maintaining cultural patterns.

On the other hand, the cultural system as the custodian of cultural patterns has provided a certain set of norms and values during this pandemic that every individual in society must adhere (Radclife-Brown, 1980, p. 22).

Therefore, while undergoing online learning, teachers, parents and students must continue to follow the norms that apply during the Covid-19 pandemic. For example, continuing to comply with health protocols by diligently washing hands with clean water and soap, wearing a mask if you have to leave the house and regularly consuming foods and drinks that can increase the body's immunity.

\section{Conclusion}

The Covid-19 pandemic has forced significant social changes in the world of education. For example, the change in the education system from offline learning to online learning. In the context of the Covid-19 pandemic, this social change creates a new cultural pattern known as the New Normal. In order not to experience delays in responding to a new culture (cultural lag), this article offers a functional structural theory initiated by Parsons to examine online learning, through the AGIL scheme. This article recommends all parties involved and interested in education; immediately to adapt with online learning which is generally carried out during the Covid-19 pandemic, so that online learning continues to meet the educational and learning objectives that have been declared. Therefore, integration between three educational centers is needed, namely schools, families and communities, so that education as a cultural pattern inherent in Indonesian society is maintained, even during the Covid-19 pandemic. 
However, those who are actively involved in online learning must continue to meet new cultural patterns during the Covid-19 pandemic, especially the culture of complying with health protocols.

\section{BIBLIOGRAPHY}

Adhetya Cahyani, I. D. (2020). Motivasi Belajar Siswa SMA pada Pembelajaran Daring di Masa Pandemi Covid-19. IQ (Ilmu Alqur'an): Jurnal Pendidikan Islam, 3(1), 123-140. doi:10.37542/iq.v3i01.57

Craib, I. (1986 ). Teori-Teori Sosial Modern. Jakarta : Rajawali.

Dimyathi, S. (2017). KH. A. Dimyathi Romly: Ayah, Guru dan Pembimbing Umat. Jakarta: Elex Media Komputindo.

Emda, A. (2017). Kedudukan Motivasi Belajar Siswa dalam Pembelajaran . Lantanida Journal, 5(2), 93-196.

George Ritzer, D. J. (2014). Teori Sosiologi: Dari Teori Sosiologi Klasik Sampai Perkembangan Mutakhir Teori Sosial Postmodern. Yogyakarta: Kreasi Wacana.

Ichsan, A. S. (2020 ). Pandemi Covid-19 dalam Telaah Kritis Sosiologi Pendidikan. Magistra: Jurnal Keguruan dan Ilmu Pendidikan, 7(2), 98114 .

Isa Anshori, Z. I. (2020). Dampak Covid-19 terhadap Proses Pembelajaran di MTs Al-Asyhar Bungah Gresik. Islamic Management: Jurnal Manajemen Pendidikan Islam, 3(2), 181-199. doi:10.30868/im.v3i02.803

Kementerian Pendidikan dan Kebudayan. (2020, May 19). SE Sesjen: Pedoman Penyelenggaraan Belajar dari Rumah dalam Masa Darurat Penyebaran Covid-19. Retrieved from https://www.kemdikbud.go.id/main/blog/2020/05/se-sesjenpedoman-penyelenggaraan-belajar-dari-rumah-dalam-masadarurat-penyebaran-covid19.

Komite Penanganan Covid-19 dan Pemulihan Ekonomi Nasional (KPC PEN). (2020, April 13). Keputusan Presiden Republik Indonesia Nomor 12 Tahun 2020 tentang Penetapan sebagai Bencana Nasional. Retrieved 
from https://covid19.go.id/p/regulasi/keputusan-presiden-republikindonesia-nomor-12-tahun-2020.

Lilik Agustina, R. O. (2017). Pengaruh Motivasi Belajar terhadap Hasil Belajar Sosiologi di SMA. Jurnal Pendidikan dan Pembelajaran Khatulistiwa, 6(5), 1-13.

Maunah, B. (2019). Pendidik dan Guru Muslim dalam Perspektif Sosiologis. Cendekia , 13(2), 99-114. doi:10.30957/cendekia.v13i2.599

Nasution, S. (2009). Sosiologi Pendidikan. Jakarta: Bumi Aksara.

Poncojari Wahyono, H. H. (2020). Guru Profesional di Masa Pandemi Covid-19: Review Implementasi, Tantangan dan Solusi Pembelajaran Daring. Jurnal Pendidikan Profesi Guru, 1(1), 51-65.

Pusdiklat Kemdikbud. (2020, March 24). Surat Edaran Mendikbud No 4 Tahun 2020 tentang Pelaksanaan Kebijakan Pendidikan dalam Masa Darurat Penyebaran Corona Virus Disease (Covid-19). Retrieved from https://pusdiklat.kemdikbud.go.id/surat-edaran-mendikbud-no-4tahun-2020-tentang-pelaksanaan-kebijakan-pendidikan-dalammasa-darurat-penyebaran-corona-virus-disease-covid-1-9/.

Radclife-Brown, A. R. (1980). Struktur dan Fungsi dalam Masyarakat Primitif. Kuala Lumpur: Dewan Bahasa dan Pustaka.

Rahmah Fitriyani, R. F. (2020). Pelaksanaan Student Centered Learning Berbasis Online pada Pembelajaran Sosiologi Siswa Kelas X IPS SMA Negeri 4 Bukittinggi Masa Pandemi Covid-19. Jurnal Sikola: Jurnal Kajian Pendidikan dan Pembelajaran, 2(1), 8-18. doi:https://doi.org/10.24036/sikola.v2i1.64

Rasyid, M. R. (2015). Pendidikan dalam Perspektif Teori Sosiologi. Auladuna, 2(2), 274-286.

Ria Yunitasari, U. H. (2020). Pengaruh Pembelajaran Daring terhadap Minat Belajar Siswa pada Masa COVID-19. Edukatif: Jurnal Ilmu Pendidikan, 2(3), 232-243.

Ritzer, G. (2013). Sosiologi Ilmu Pengetahuan Berparadigma Ganda. (Alimandan, Trans.) Jakarta: RajaGrafindo Persada. 
Rizki Setiawan, E. K. (2020 ). Membangun Efektifitas Pembelajaran Sosiologi di Tengah Pandemi Covid-19 . Edusocius: Jurnal Ilmiah Penelitian Pendidikan dan Sosiologi, 4(1), 1-13.

Rusman. (2014). Model-Model Pembelajaran: Mengembangkan Profesionalisme Guru. Jakarta: RajaGrafindo Persada.

Sadirman, A. (2012). Interaksi dan Motivasi Belajar Mengajar. Jakarta: RajaGrafindo Persada.

Sudrajat, J. (2020). Kompetensi Guru di Masa Pandemi Covid-19. Jurnal Riset Ekonomi dan Bisnis , 13(1), 100-110 .

Suryaningsih, A. (2020). Peningkatan Motivasi Belajar Siswa Secara Online pada Pelajaran Animasi 2D Melalui Strategi Komunikasi Persuasif. Ideguru : Jurnal Karya Ilmiah Guru, 5(1), 9-15.

Susanto, A. (2016). Manajemen Peningkatan Kinerja Guru: Konsep Strategi dan Implementasinya. Jakarta: Prenada Media Group.

Syaharuddin, M. (2020). Strategi Pembelajaran IPS: Konsep dan Aplikasi. Banjarmasin: Program Studi Pendidikan IPS FKIP Universitas Lambung Mangkurat.

Syawaludin, M. (2014). Alasan Talcott Parsons tentang Pentingnya Pendidikan Kultur. Ijtimaiyya: Jurnal Pengembangan Masyarakat Islam, 7(1), 149-166.

Zed, M. (2014). Metode Penelitian Kepustakaan. Jakarta: Yayasan Obor Indonesia. 